\title{
Regulation of plasma aldosterone during hemodialysis
}

\author{
B.K. KRÄMER, T.M. ULSHÖFER, G.A. MÜLLER, K.M. RESS, T. RISLER
}

Section of Nephrology and Hypertension, III. Department of Internal Medicine, University of Tübingen, Tübingen - FRG

\begin{abstract}
In order to clarify the influence of serum potassium, serum sodium and plasma angiotensin /I concentrations on aldosterone release during hemodialysis (HD), six chronic hemodialysis patients were studied during $H D$ with varying dialysate sodium concentrations and different buffers. Plasma aldosterone concentrations were higher during acetate than bicarbonate $H D$, during low sodium compared to high sodium $H D$, and were correlated inversely to serum sodium concentrations. The decline in plasma aldosterone concentrations during HD paralleled the decrease in serum potassium concentrations, and plasma aldosterone concentrations were correlated with serum potassium concentrations. In addition, plasma aldosterone and plasma angiotensin $/ 1$ concentrations were correlated significantly. It is proposed that serum potassium and the renin-angiotensin system are the main factors of aldosterone release during hemodialysis, while serum sodium per se seems to be of less importance. The dialysate buffer employed also plays a role in aldosterone regulation (via the renin-angiotensin system) (Int J Artif Organs 1990; 13: 32-8).
\end{abstract}

KEY WORDS: Hemodialysis, Aldosterone regulation, Angiotensin "I

\section{INTRODUCTION}

The regulation of aldosterone secretion has been the subject of various studies (1-3; reviews of literature) and serum potassium, angiotensin $\mathrm{II}$ and serum sodium concentrations, with $\mathrm{ACTH}$, are widely accepted as the main factors regulating aldosterone secretion both in normal subjects and patients with end-stage renal disease. Rises in plasma angiotensin $\mathrm{II}$ and serum potassium concentrations, and plasma $\mathrm{ACTH}$, and decreases in serum sodium concentrations and plasma volume are known to stimulate aldosterone secretion. The major transduction mechanisms are activation of phospholipase $\mathrm{C}$, activation of adenylate cyclase, calcium influx and calcium release (3).

The aim of the present study was to investigate the relationship between plasma aldosterone and serum potassium, serum sodium, and plasma angiotensin 11 concentrations in relation to different dialysate sodium concentrations and dialysate buffers during hemodialysis (HD).

\section{PATIENTS AND METHODS}

Six patients with end-stage renal disease were examined during a regular $4 \mathrm{~h}$ acetate $\mathrm{HD}$ at one of four dialysate sodium concentrations $(135,140,145$, $150 \mathrm{mmol} / \mathrm{l}$ ) and five of those patients during bicarbonate $H D$ at the same four dialysate sodium concentrations (each patient was studied at one of the four dialysate sodium concentrations). In each case a $\mathrm{HD}$ procedure using the same protocol with regard to buffer and dialysate sodium concentration was performed two days before the HD procedure included in our study.

The mean age of the patients was 46.2 years (1766 ), and they had been on chronic HD treatment for 2.7 years (0.5-7.0); the etiology of the renal failure was polycystic kidneys, pyelonephritis or hydronephrosis. No patient was bilaterally nephrectomized, and none received antihypertensive treatment.

Blood samples were obtained from the arterial line, before dialysis, after $80 \mathrm{~min}$, after $160 \mathrm{~min}$, and after 
$4 \mathrm{~h}$ of dialysis and concentrations of aldosterone and angiotensin II were measured by commercially available kits (Fa. H. Biermann Medizinische Systeme GmbH, Bad Nauheim, FRG: Coat-A-Count Aldosteron and J-125 Angiotensin II). Sodium and potassium concentrations were measured with ion-selective electrodes (Nova 1, Nova Biomedical GmbH, Darmstadt, FRG). Hormone and electrolyte concentrations were corrected for hemoconcentrations, using hematocrit as a measure.

Dialysate was prepared using dialysate preparations (PGS 22 (Fa. Fresenius AG, Bad Homburg, FRG) and $8.4 \% \mathrm{NaHCO}_{3}$ for bicarbonate dialysis, Y108 (Fa. B. Braun, Melsungen, FRG) for acetate dialysis and dialysate sodium and potassium concentrations were checked by direct measurements. Final dialysate concentrations were: potassium 2.0-2.2 mmol/l; sodium $135,140,145,150 \mathrm{mmol} / \mathrm{l}$; bicarbonate $31-35 \mathrm{mmol} / \mathrm{l}$ (+ $3 \mathrm{mmol} / \mathrm{l}$ acetate); acetate $35-39 \mathrm{mmol} / \mathrm{l}$.

The HD procedure was as follows: $4 \mathrm{~h}$ three times per week, blood flow $250 \mathrm{ml} / \mathrm{min}$, dialysate flow 444 $\mathrm{ml} / \mathrm{min}$ (Cobe Centry $2000 \mathrm{Rx}$, Cobe Laboratories $\mathrm{GmbH}$, Kirchheim, FRG); dialyser: $1.4 \mathrm{~m}^{2}$ surface, saponified cellulose ester (C-DAK Artificial Kidney 135 sce, CD Medical GmbH, München, FRG).

Statistical analysis was done by Student's paired ttest and the correlation coefficient. $P$ values $<0.05$ were considered statistically significant and data are given as mean \pm SEM .

\section{RESULTS}

Angiotensin 11 concentration was $90.0 \pm 9.9 \mathrm{pg} / \mathrm{ml}$ $(\mathrm{n}=96)$ during acetate $\mathrm{HD}$ and $28.9 \pm 1.7 \mathrm{pg} / \mathrm{ml}(\mathrm{n}=$ $80)$ during bicarbonate HD $(p<0.0001$; range of normal values $5-15 \mathrm{pg} / \mathrm{ml} ; 63.6 \pm 10.8 \mathrm{pg} / \mathrm{ml}$ for all values obtained during either acetate or bicarbonate HD). Angiotensin II concentrations at different dialysate sodium concentrations during acetate or bicarbonate dialysis are set out in Figure 1 and were significantly higher $(p<0.001)$ during acetate than bicarbonate $H D$ at 135 and $140 \mathrm{mmol} / \mathrm{l}$, lower during bicarbonate than acetate $\mathrm{HD}$ at $150 \mathrm{mmol} / \mathrm{l}$ ( $\mathrm{p}$ $<0.001$ ).

Angiotensin II concentrations during the course of acetate and bicarbonate $\mathrm{HD}$ are shown in Figure 2 . Aldosterone concentration was $573 \pm 60 \mathrm{pg} / \mathrm{ml}$ ( $\mathrm{n}=$

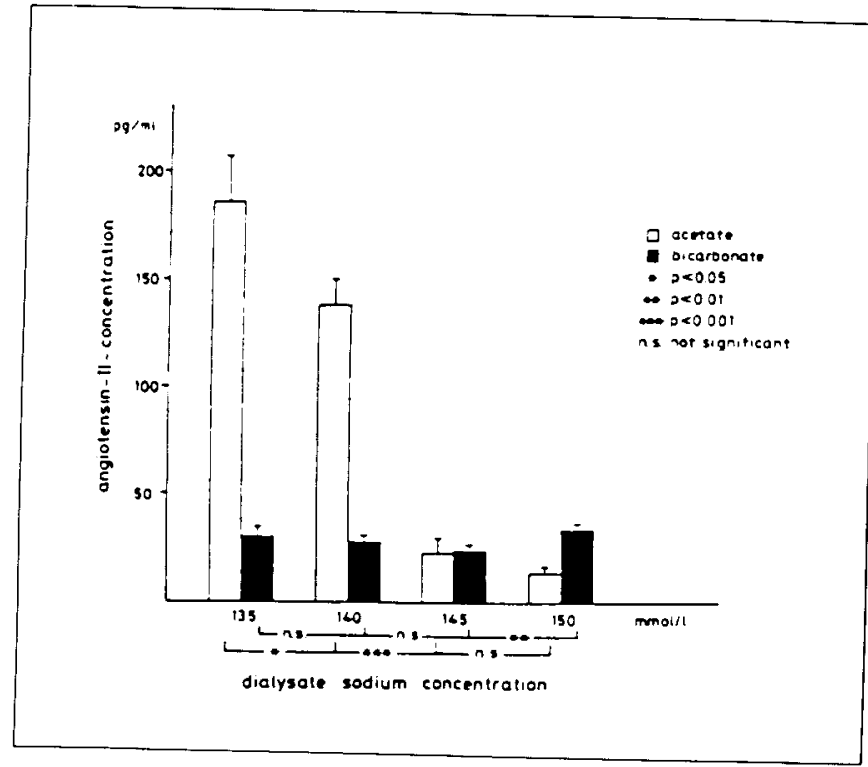

Fig. 1 - Plasma angiotensin concentrations during hemodialysis with acetate or bicarbonate at different dialysate sodium concentrations (means + SEM of all values obtained at all time points at a given dialysate sodium concentration and a given buffer).

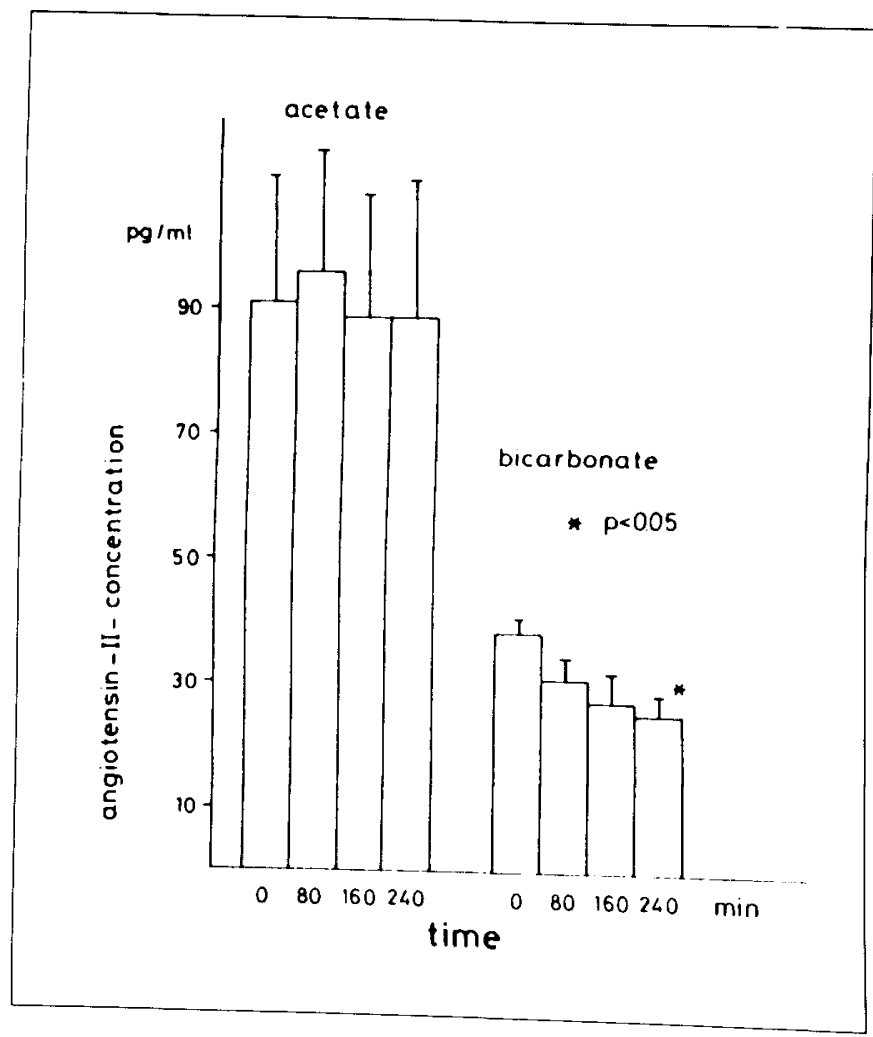

Fig. 2 - Plasma angiotensin concentrations at four time points during acetate or bicarbonate hemodialysis (means $\pm S E M$ of
all values obtained at all four dialysate sodium concentrations). 


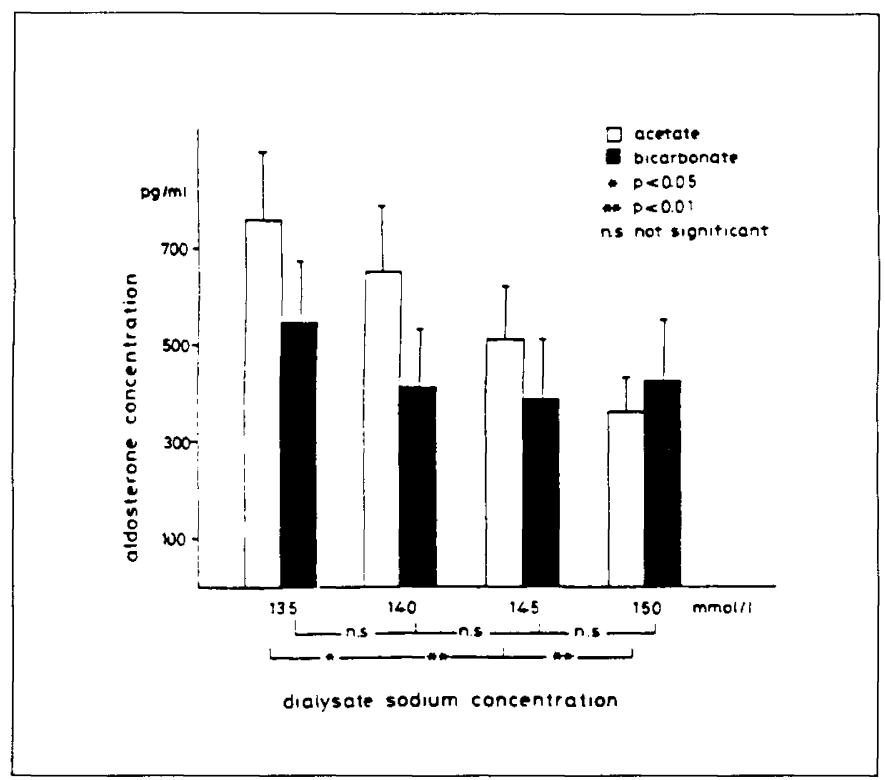

Fig. 3 - Plasma aldosterone concentrations during hemodialysis with acetate or bicarbonate at different dialysate sodium concentrations (means \pm SEM of all values obtained at all time points).

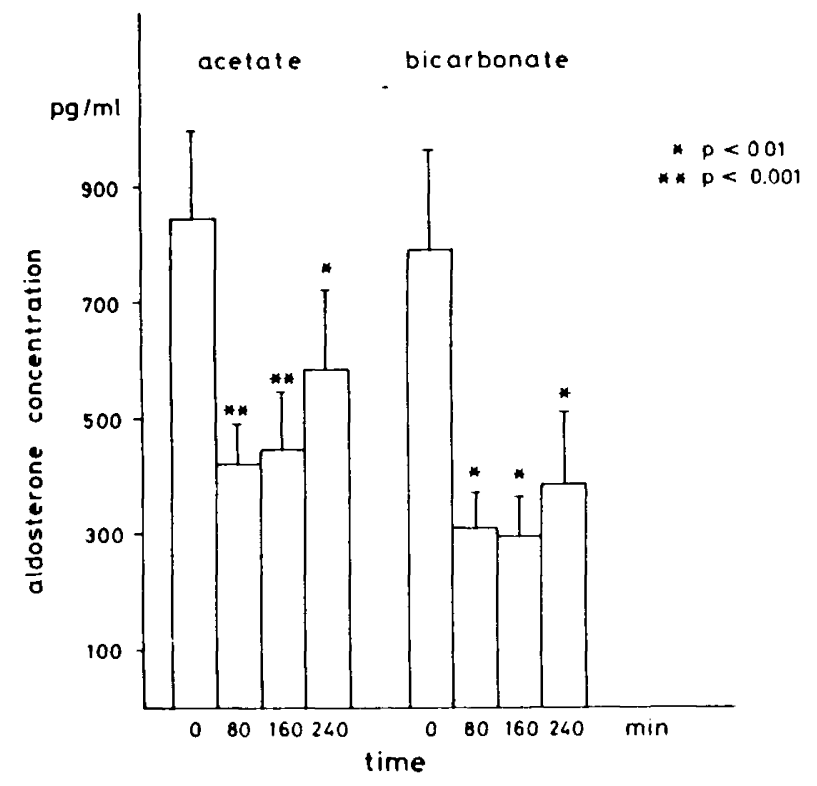

Fig. 4 - Plasma aldosterone concentrations at four time points during acetate or bicarbonate hemodialysis (means $\pm S E M$ at all dialysate sodium concentrations).

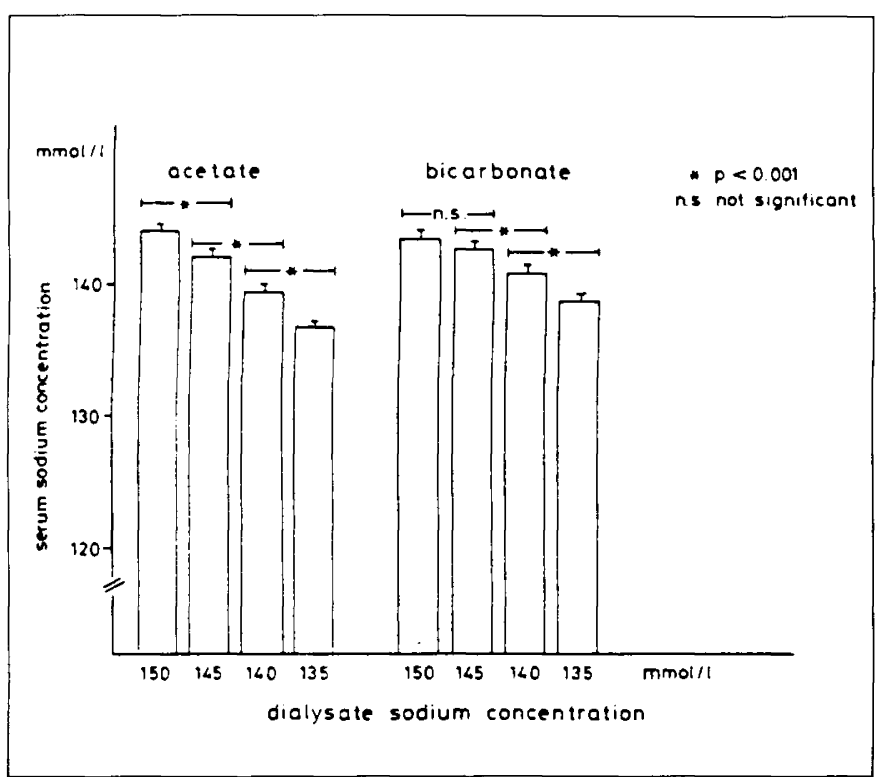

Fig. 5 - Serum sodium concentrations during hemodialysis with acetate or bicarbonate at different dialysate sodium concentrations (means $\pm S E M$ at all time points).

96) during acetate $\mathrm{HD}$ and $446 \pm 62 \mathrm{pg} / \mathrm{ml}(\mathrm{n}=80)$ during bicarbonate HD ( $p<0.05$; range of normal values $10-160 \mathrm{pg} / \mathrm{ml} ; 509 \pm 74 \mathrm{pg} / \mathrm{ml}$ for all values obtained during acetate or bicarbonate HD).

Figures 3 and 4 give aldosterone concentrations at different dialysate sodium concentrations and dialysate buffers, and during the course of dialysis. Plasma aldosterone was significantly higher during $\mathrm{HD}$ at 140 $\mathrm{mmol} / \mathrm{l}(\mathrm{p}<0.05)$ and at $145 \mathrm{mmol} / \mathrm{l}(\mathrm{p}<0.01)$ with acetate than with bicarbonate; the differences were not significant at 135 and $150 \mathrm{mmol} / \mathrm{l}$. Serum sodium concentrations were higher at high than at low dialysate sodium concentrations, during both bicarbonate and acetate HD (Fig. 5).

Serum sodium concentration decreased during acetate $\mathrm{HD}$ at low dialysate concentrations and increased during bicarbonate $\mathrm{HD}$ at $150 \mathrm{mmol} / \mathrm{l}$ dialysate sodium concentration (Figs. 6 and 7). The decreases in serum potassium concentrations were very similiar during dialysis with both dialysate buffers (Figs. 8 and 9). Despite these results small but significant differences were observed in serum potassium concentration at low compared to high dialysate sodium concentrations (Fig. 10).

Angiotensin II concentration was correlated nega- 


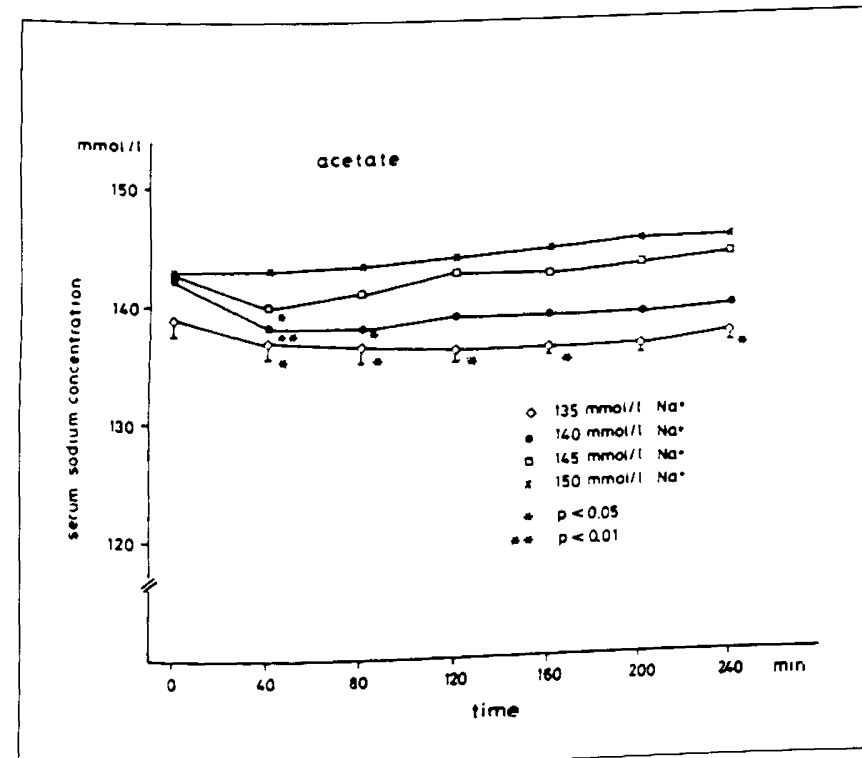

Fig. 6 - Serum sodium concentrations during acetate hemodialysis at different dialysate sodium concentrations (means; for reasons of legibility SEM is only given at $135 \mathrm{mmol} / \mathrm{l}$ dialysate sodium concentration).

tively with serum sodium concentration $(p<0.01)$ during acetate but not during bicarbonate dialysis. Angiotensin II concentration was also correlated positively $(p<0.01)$ with aldosterone concentration during $H D$ with both dialysate buffers. Aldosterone concentration was correlated positively to serum potassium concentration $(p<0.01)$ and negatively to serum sodium concentration $(p<0.01)$ during acetate or bicarbonate dialysis.

Mean volume removal was nearly identical during acetate and bicarbonate $H D(2.15 \mathrm{~L} / 2.10 \mathrm{~L})$.

\section{DISCUSSION}

Serum aldosterone is elevated in most patients with end-stage renal disease. It is dependent on serum potassium/dialysate potassium during $H D$, although there are some contradictory data, whereas little information is available on aldosterone regulation during hemodialysis with different dialysate buffers (2, 4-19).

This study, like others, found elevated serum aldosterone concentrations. Serum aldosterone was higher during acetate than during bicarbonate $H D$. It was also higher during low-sodium than high-sodium HD, when acetate not bicarbonate was employed. These

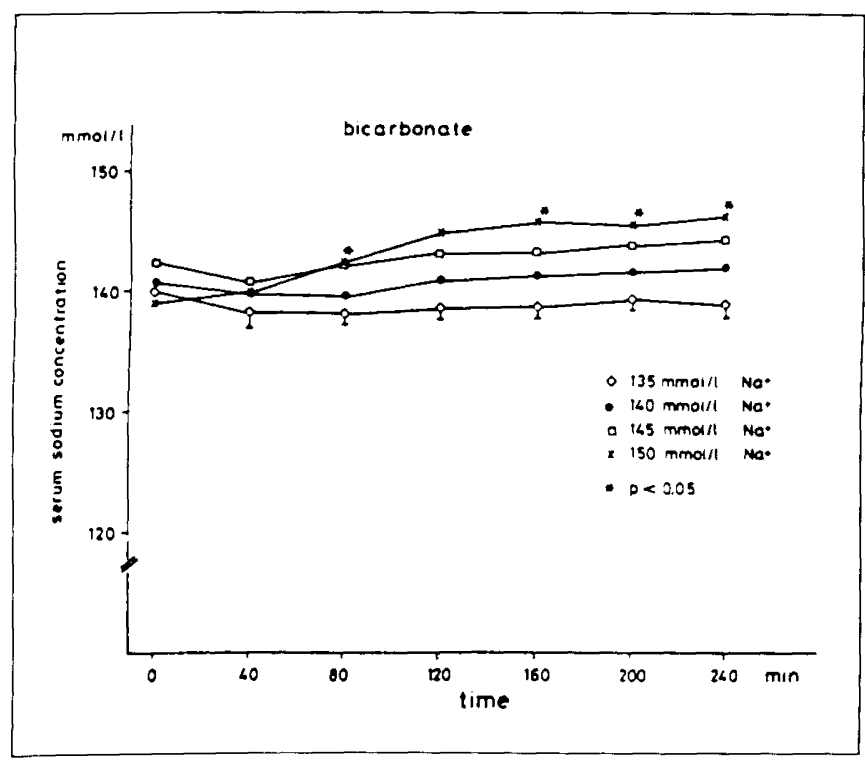

Fig. 7 - Serum sodium concentrations during bicarbonate hemodialysis at different dialysate sodium concentrations (means; for reasons of legibility SEM is only given at 135 $\mathrm{mmol} /$ / dialysate sodium concentration).

buffer-related differences in aldosterone concentrations cannot be explained by differences in serum potassium concentrations. The slightly higher serum potassium concentrations during high-sodium hemodialysis might be due to minute differences in dialysate potassium concentrations, although serum potassium decreased in a parallel manner at all dialysate sodium concentrations (Figs. 8 and 9). If those differences in serum potassium concentrations exert any effect at all on aldosterone concentration, then serum aldosterone concentrations ought to be higher during highsodium (associated with slightly higher serum potassium concentrations) than during low-sodium HD, thus possibly reducing a real difference.

The decrease in aldosterone concentration during hemodialysis with either acetate or bicarbonate and the positive correlation between serum potassium and plasma aldosterone concentrations confirm the major role of potassium for aldosterone regulation in patients with end-stage renal disease. These data are in accordance with most Authors (2, 8-10, 13, 15-19, 23), but disagree with the results of Ratge et al. (14). The loss of aldosterone across the dialyser membrane during hemodialysis seems to be of little importance (10).

Serum sodium concentration, a known factor in aldosterone regulation (1-3), shows no major diffe- 


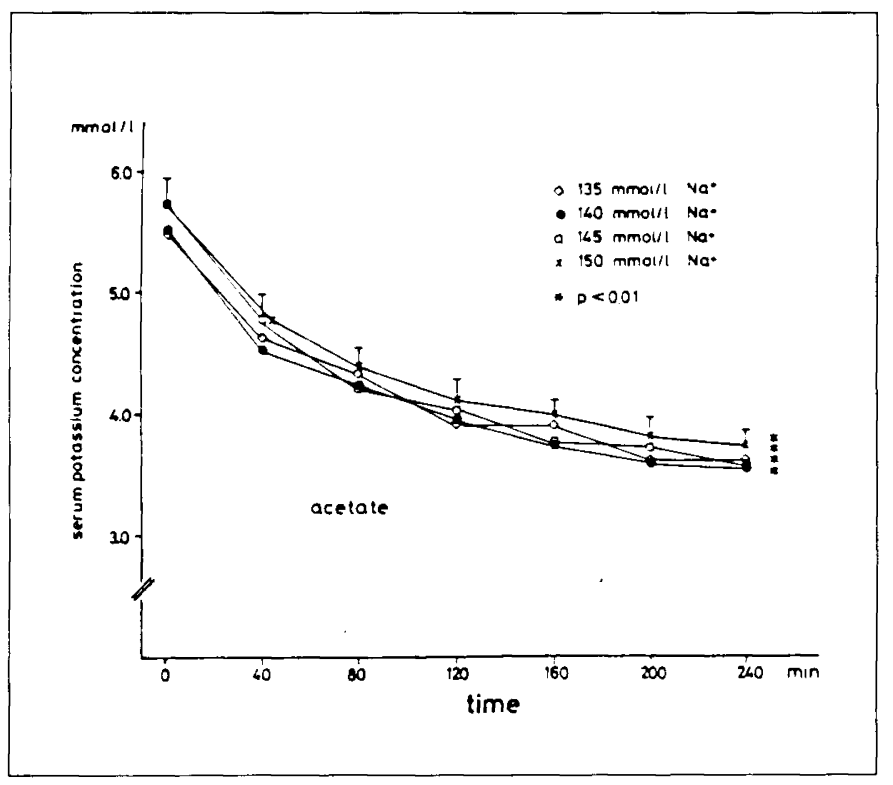

Fig. 8 - Serum potassium concentrations during acetate hemodialysis at different dialysate sodium concentrations (means; for reasons of legibility SEM is only given at $150 \mathrm{mmol} / \mathrm{l}$ dialysate sodium concentration).

rences during HD with different buffers and it thus probably has no effect on aldosterone release in different ways during acetate and bicarbonate $\mathrm{HD}$. However, using the same dialysate buffer, plasma aldosterone concentration was higher during lowsodium than during high-sodium acetate HD (with insignificant differences during bicarbonate HD). A correlation between serum sodium and plasma aldosterone concentrations was shown during $H D$ with eitiver acetate or bicarbonate, thus confirming the known effects of serum sodium concentration on aldosterone release $(1,2,16,20)$.

Besides serum potassium and serum sodium concentrations, angiotensin 11 is a major aldosterone regulating factor (1-3). During acetate but not during bicarbonate HD the angiotensin II concentration was higher at low than at higher dialysate sodium concentrations. In addition the angiotensin II concentration was higher with low-sodium acetate HD than low-sodium bicarbonate HD; this provides an explanation of the buffer-related differences in plasma aldosterone concentrations. However, there is no explanation for the rather high angiotensin II concentration during bicarbonate $\mathrm{HD}$ at $150 \mathrm{mmol} / \mathrm{l}$. The

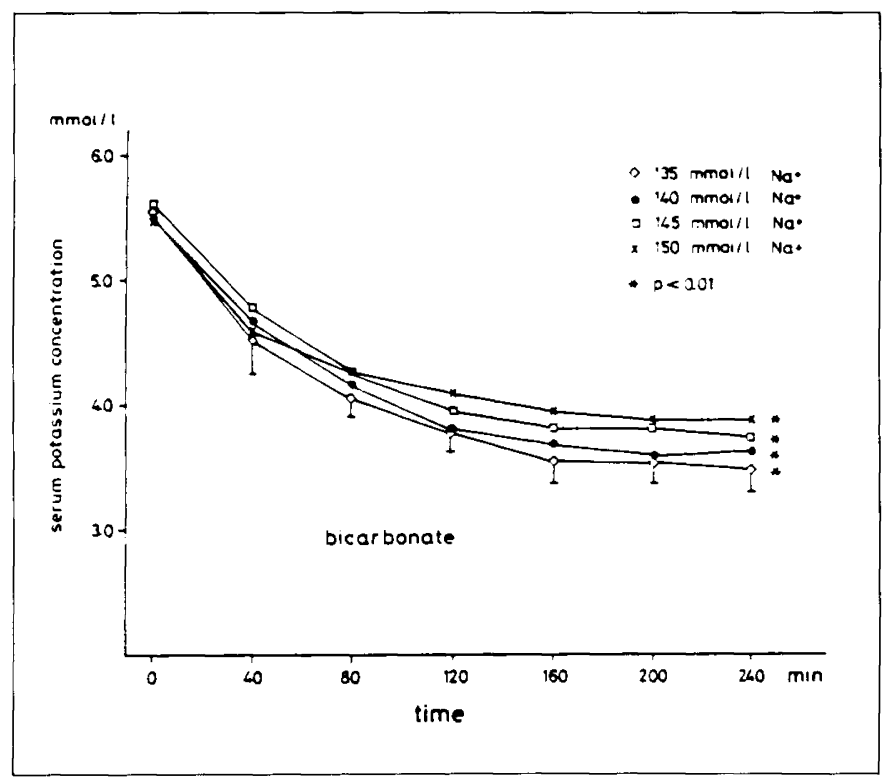

Fig. 9 - Serum potassium concentrations during bicarbonate hemodialysis at different dialysate sodium concentrations (means; for reasons of legibility SEM is only given at 145 mmol/( dialysate sodium concentration).

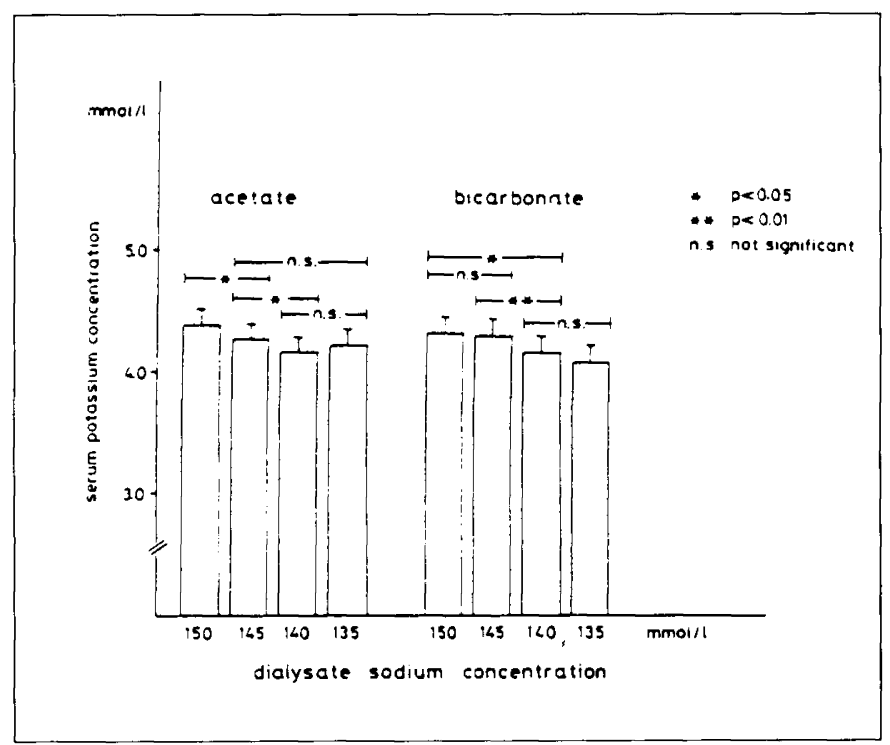

Fig. 10 - Serum potassium concentrations during hemodialysis with acetate or bicarbonate at different dialysate sodium concentrations (means \pm SEM at all time points).

decrease in angiotensin 11 concentration seen during bicarbonate HD was not observed during acetate HD and this provides further support for the assumption that angiotensin II formation rates are higher during 
acetate than bicarbonate HD. The higher rate of stimulation of the renin-angiotensin-aldosterone system is probably secondary to the vasodilating effect of acetate (11; discussion of literature) and the slower refilling of plasma volume during acetate HD (21).

Greater plasma renin activity during acetate than bicarbonate $H D$, an actual increase of plasma renin activity during acetate but not during bicarbonate $\mathrm{HD}$ (11), and more stable blood pressure regulation during bicarbonate HD (12) have all been demonstrated. Igarashi et al. (22) have shown elevated angiotensin II concentrations before and during HD in hypertensive patients on chronic HD. The differences in predialytic angiotensin $\|$ concentrations before acetate and bicarbonate $H D$ are thought to be due to the different dialysate buffers in chronically treated patients, although the role of dialysate sodium concentration and buffers on the interdialytic renin-angiotensin-aldosterone system were not investigated in the present study. Further studies are necessary to clarify the roles of different dialysate buffers in relation to different dialysate sodium concentrations on interdialytic regulation of the renin-angiotensin-aldosterone system.

Reprint requests to:

Prof. Dr. Teut Risler

III. Department of Internal Medicine

University of Tübingen

Otfried-Müller-Str. 10

D-7400 Tübingen, FRG

\section{REFERENCES}

1. Coghlan JP, Blair-West JR, Denton DA, et al. Control of aldosterone secretion. J Endocr 1979; 81: 55-67.

2. Olgaard K. Plasma aldosterone regulation in anephric and non-nephrectomized patients on regular hemodialysis. Danish Med Bull 1980; 27: 22-35.

3. Quinn SJ, Williams GH. Regulation of aldosterone secretion. Ann Rev Physiol 1988; 50: 409-26.

4. Coruzzi P, Novarini A, Musiari L, Rossi E, Borghetti A. Effects of "Central Hypervolemia" by water immersion on renin-aldosterone system and ACTH-cortisol axis in hemodialyzed patients. Nephron 1984; 36: 238-41.

5. Hammer M, Dawids S, Bredgaard Sorensen M, Christensen O, Ølgaard K. Hormonal response to volume depletion in non-nephrectomised patients on regular haemodialysis. Proc EDTA 1979; 16: 252-8

6. Hené RJ, Boer P, Koomans HA, Dorhout Mees EJ Plasma aldosterone concentrations in chronic renal disease. Kidney Int 1982; 21: 98-101.

7. Hené RJ, Koomans HA, Boer P, Roos JC, Dorhout Mees EJ. Relation between plasma aldosterone concentration and renal handling of sodium and potassium, in particular in patients with chronic renal failure. Nephron 1984; 37: 94-9.
8. Henrich WL, Katz FH, Molinoff PB, Schrier RW. Competitive effects of hypokalemia and volume depletion on plasma renin activity, aldosterone and catecholamine concentrations in hemodialysis patients. Kidney Int 1977; 12: 279-84.

9. Hory B, Henriet MT. Etude des variations de l'aldostéronémie, de l'activité rénine plasmatique et des taux sériques de l'enzyme de conversion pendant la dialyse au bicarbonate dans l'insuffisance rénale chronique. Nephrologie 1983; 4: 229-30.

10. litake K, Kimura T, Matsui K, et al. Effect of haemodialysis on plasma $A D H$ levels, plasma renin activity and plasma aldosterone levels in patients with end-stage renal disease. Acta Endocrinol 1985; 110: 207-13.

11. Krämer BK, Ress KM, Ulshöfer TM, Risler T. The renin-angiotensin-aldosterone system during haemodialysis with acetate or bicarbonate at different dialysate sodium concentrations. Nephrol Dial Transplant 1987; 2: $521-36$

12. Krämer BK, Ress KM, Ulshöfer TM, Risler T. Hemodynamic and hormonal effects of low or high sodium hemodialysis. Kidney Int 1988; 34 (suppl 25): $192-5$ 
13. Krause JZ, Matarese RA, Zabetakis PM, Michelis MF. Reversibility of hyporeninemia and hypoaldosteronemia in chronic hemodialysis patients by correction of fluid excess. J Lab Clin Med 1980; 96: 734-42.

14. Ratge D, Augustin R, Wisser $H$. Catecholamines, renin, aldosterone and arterial pressure in patients on chronic hemodialysis treatment. Int $J$ Artif Organs 1983; 6: 255-60.

15. Olgaard K, Madsen S. Regulation of plasma aldosterone in anephric and non-nephrectomized patients during hemodialysis treatment. Acta Med Scand 1977; 201: 457-62.

16. Van Stone JC, Bauer J, Carey J. The effect of dialysate sodium concentration on body fluid compartment volume, plasma renin activity and plasma aldosterone concentration in chronic hemodialysis patients. Am J Kidney Dis 1982; 2; 58-64.

17. Vetter W, Záruba K, Armbruster $\mathrm{H}$, et al. Control of plasma aldosterone during hemodialysis in patients with terminal renal failure. Nephron 1977; 18: 11423.
18. Weidmann P, Maxwell MH, Lupu AN. Plasma aldosterone in terminal renal failure. Ann Intern Med 1973; 78: 13-8.

19. Weidmann P, Maxwell MH, De Lima J, Hirsch D, Franklin SS. Control of aldosterone responsiveness in terminal renal failure. Kidney Int 1975; 7 : 351-9.

20. McCaa RE, Bower JD, McCaa CS. Relative influence of acute sodium and volume depletion on aldosterone secretion in nephrectomized man. Circulation Res 1973; 33: $555-62$

21. Hsu CH, Swartz RD, Somermeyer MG, Raj A. Bicarbonate hemodialysis: influence on plasma refilling and hemodynamic stability. Nephron 1984; 38: 202-8.

22. Igarashi $Y$, Suzuki $H$, Imafuka $T$, Saito I, Saruta $T$. Hypertension in patients on chronic hemodialysis: the role of the renin-angiotensin system. Jpn Circ J 1987; 51: $479-84$

23. Elias AN, Vaziri ND, Pandian MR, Kaupke J. Plasma concentrations of atrial natriuretic peptide, anginine vasopressin and hormones of the renin-angiotensin system in patients with end-stage renal disease. Int $\mathrm{J}$ Artif Organs 1989; 12: 153-8. 